\title{
Downward Trend in the Frequency of Destructive Hailstorms and Maximum Hailstone Size in England and Wales
}

\author{
Colin Clark \\ CHRS, Shute Lane, Bruton, Somerset, UK \\ Email: colin4chrs@hotmail.com
}

How to cite this paper: Clark, C. (2020). Downward Trend in the Frequency of Destructive Hailstorms and Maximum Hailstone Size in England and Wales. Journal of Geoscience and Environment Protection, 8, 57-70.

https://doi.org/10.4236/gep.2020.84005

Received: February 21, 2020

Accepted: April 18, 2020

Published: April 21, 2020

Copyright $\odot 2020$ by author(s) and Scientific Research Publishing Inc. This work is licensed under the Creative Commons Attribution International License (CC BY 4.0).

http://creativecommons.org/licenses/by/4.0/

\section{(c) (i) Open Access}

\begin{abstract}
By their definition, destructive hailstorms cause a great deal of damage to property and have been known to be fatal to humans. At present the long term changes in the frequency of these storms are unknown. Records of destructive hailstorms from many different sources in England and Wales go back for several centuries. Recently discovered records of over 30 destructive hailstorms have allowed a better description of hailstorm history since 1780 . The data were grouped into 30,40 , and 50 year non-overlapping time periods in relation to time. Increases in their frequency in the $17^{\text {th }}$ and $18^{\text {th }}$ centuries were probably due to an increase in population and better recording. Since 1900 the frequency has significantly declined so that in the present 50 year time period only 22 have been recorded as compared with an average of 49 in both halves of the $19^{\text {th }}$ century. The decline in frequency may be partly due to the big increase in particulate matter from aviation, which leads to a much higher concentration of ice and cloud condensation nuclei, resulting in fewer destructive hailstorms.
\end{abstract}

\section{Keywords}

Destructive Hailstorms Downward Trend

\section{Introduction and Reasons for Study}

Worldwide, hailstorms are a major cause of weather-related damage (Prein \& Holland, 2018) with the US incurring over $\$ 11$ bn average annual losses from 2003-2015 (Gunturi \& Tippett, 2017). At present there is a big discrepancy between the findings of empirical studies of the historic changes in hailstorm frequency and hailstone size and the theoretical estimates of what may happen in 
the future. The first section of this paper and the main purpose of science are to provide a reliable description of nature. The process of obtaining this knowledge, especially if an event took place a long time ago, depends on at least six separate stages. The second section of this paper provides an historic record of destructive hailstorms from 1650. The third section is an analysis of their frequency based on three different sized time periods for comparison. Observations of maximum hailstone size going back to the $15^{\text {th }}$ century are also included. In the fourth section a tentative explanation for the changes is given. In the fifth section comparisons are made with previously published work. The final section includes the conclusions and discussion.

\section{Data Base of Severe Hailstorms}

Any natural event will only be known in the present if all of the following stages have been fulfilled:

1) The event;

2) An observer to record or remember the event;

3) Evidence of the effects;

4) A written record;

5) Preservation of the record;

6) The record being found in the archives or other material.

Records of past events exist in numerous sources. While the list of past hailstorms presented here may not be complete so far as the record could show, it is based on a search through original documents in County Record Offices, historical chronologies, compilations, scientific and other journals and a unique source of insurance records based mainly in East Anglia. The first Insurance Company, based in London, was the Farmers and Gardeners Hailstorm Ins. Co. started in 1842, followed the year after by the General Hailstorm Insurance Co. at Norwich (Walford, 1878).

Since 1974 the Tornado and Storm Research organisation (TORRO) has gathered details of hailstorms and other severe weather events (Webb, Elsom, \& Meaden, 2009; Doe, 2016). Appendix A of Doe (2016), only available on the web http://www.wiley.com/go/doe/extremeweather gives a list of events which equal level H4-5+ on the revised TORRO scale (Sioutas, Meaden, \& Webb 2009). To this must be added 2 July 2015 (Clark et al., 2018), and 27 July 2018 http://www.examinerlive.co.uk/news/west-yorkshire-news/huge-golf-ball. These are referred to as $\mathrm{H} 5+$ or destructive where the scale runs from $\mathrm{H} 0$ to $\mathrm{H} 10$. Following further research by the author this list is now extended to include 31 additional events which mainly took place before 1800. Table 1 shows the details and source of these events, ten of which are recorded in the Insurance Cyclopaedia (Walford, 1878). This important source of events came about because of the formation of Insurance Companies which specialised in hailstorm insurance. This allowed farmers to take out insurance cover against crop damage. The success or failure of an insurance company depended upon the best available knowledge of destructive hailstorms. There is one instance near Whitchurch in Hampshire 
Table 1. List of additional destructive hailstorms since 1650.

\begin{tabular}{|c|c|c|}
\hline Date & Place & Source \\
\hline Sept 31651 & Dorchester & Insurance Cyclopaedia (Walford, 1878) \\
\hline August $12 \& 171656$ & Norfolk & Insurance Cyclopaedia (Walford, 1878) \\
\hline May 291680 & London & Life and Times of Anthony Wood (1892) \\
\hline Aug 101662 & Ormskirk & Admirable Curiosities, Burton (1811) \\
\hline June 71709 & Sherborne, Dorset & Claver Morris Diary, Hobhouse (1934) \\
\hline June 1726 & Bridgwater & Bristol Journal 11/6/1726 \\
\hline June 81737 & Charlton Horethorne & Western Flying Post 31/5/1737 \\
\hline Aug 191741 & Alkborough & Lincs. Rec Office Alkborough Par/1/3 \\
\hline May 221745 & Yorkshire & Jeffery (1933); Curnock (1949) \\
\hline July 301747 & Gloucester \& Somerset & Insurance Cyclopaedia (Walford, 1878) \\
\hline July 261750 & London & Whistlecraft (1851) \\
\hline June 141754 & Cheltenham & John Wesley’s Journal 17/3/1756 \\
\hline Sept 251761 & Enfield & Insurance Cyclopaedia (Walford, 1878) \\
\hline July 161769 & Ely & Insurance Cyclopaedia (Walford, 1878) \\
\hline Aug 21783 & Belper & Leic. Record Office: DE4828/Box 5 \\
\hline May 231784 & Old Bollingbroke & Northants. Record Office: ST86 \\
\hline Aug 31789 & Amersham & Insurance Cyclopaedia (Walford, 1878) \\
\hline June 51791 & Lewes & Tablet of Memory (1811) \\
\hline July 61794 & Albourne Wiltshire & Insurance Cyclopaedia (Walford, 1878) \\
\hline Oct 191800 & Cheshire & Nature vol. 126, p. 633, 1930 \\
\hline Aug 221800 & Woburn Beds. & Insurance Cyclopaedia (Walford, 1878) \\
\hline Aug 161808 & Bristol & Insurance Cyclopaedia (Walford, 1878) \\
\hline July 211816 & Cumbria \& Staffs & Insurance Cyclopaedia (Walford, 1878) \\
\hline July 131819 & Dereham & Insurance Cyclopaedia (Walford, 1878) \\
\hline June 281826 & Berkshire \& Essex & Insurance Cyclopaedia (Walford, 1878) \\
\hline May 21841 & Lugershall & Salisbury \& Winchester J. 3/5/1841 \\
\hline July 151841 & Sussex \& Berkshire & Derby \& Chesterfield Rep. 22/7/1841 \\
\hline April 251842 & Whitchurch & Salisbury \& Winchester J. 9/5/1842 \\
\hline June 111842 & East Somerset & Somerset County Gazette 18/6/1842 \\
\hline May 6-7 1862 & Newark & Jeffery (1933) \\
\hline
\end{tabular}

during April 1842 when an Insurance Broker was advising Farmer Twynam to take out hail insurance, when a destructive hailstorm storm took place on his farm (Salisbury \& Winchester Journal, 9/5/1842).

Two attempts have been made to detect trends in destructive hailstorm frequency. The first was made by Webb (1988) who divided the record for the British Isles into pentads for the period 1866-1985 and found no trend in frequency. 
Later, Webb \& Elsom (2016) found that by using decadal totals there was some evidence of a downward trend from a peak in the late 1890's to the early 1900's. However advice from the WMO (2017) suggests that a standard climatological normal period should be at least 30 years. This could be longer especially where more extreme conditions are being studied since, a longer time period has a greater chance of including rarer events. Furthermore the use of non overlapping periods helps to identify any anomalies in the latter part of the record. Thus in this paper, for comparison, non overlapping time periods of 30, 35, and 50 years have been used to detect any trends present. To avoid counting non-independent events, only one event in a multiple outbreak on the same day is counted. This excluded over 40 events in the whole 240 year record.

The search for destructive hailstorms has been extended back into the $15^{\text {th }}$ century. However, very few events have been found, but a serious event which produces very big hailstones does stand a good chance of being recorded.

\section{Analysis of the Data and Results}

\subsection{Changes in Frequency with Different Time Bases}

Figure 1 shows the number of destructive hailstorms since around the start of the $19^{\text {th }}$ century. Each time period ends in 2019 and previous non-overlapping time periods are calculated in turn.

This explains the different number of time periods according to their respective length. Each data point is set in the middle of its time period. Taking each time period of the analysis in turn, the 30 year time base shows a slow decline from about 30 to 20 events per 30 years from the late $18^{\text {th }}$ century until the late 1920's. This is followed by a decline to less than 20 and finally to 9 in the most recent 30 year period. Changing the time base for calculation of the climatological normal period to 35 years does not change this picture much except towards the late $19^{\text {th }}$ century where there is a higher peak and an indication of a small upward trend. By using a 50 year time base this peak is accentuated and like the previous two analyses shows a marked decline which is centred around 1945.

In order to look in more detail at the temporal changes the decadal trends are shown in Figure 2. Two periods of downward trend are identified.

The first is a gradual and statistically not significant trend from 1780-1909, while the second period from 1910-2019 is more pronounced and significant at $5 \%$. The overall trend $r=-0.72$ sig $0.1 \%$. The effect of unusual data near the start or end of a data series can influence disproportionately the trend analysis (Emerson \& Hoaglin, 1983). The decades ending 1809 and 1819 had high frequencies of destructive hailstorms and when excluded from the analysis yielded $r=$ -0.68 sig. $0.1 \%$. As a further test of the difference between the two parts of the data a Mann-Whitney U test was applied to the periods 1780-1909 (1959) and 1910-2019 (1960) for a 10 year time base and 1780-1899 (1959) and 1900-2019 (1960) for a 30 year time base. This is a powerful non parametric test (Siegel, 1956), especially suitable for small sample sizes. The results are shown in Table 2 


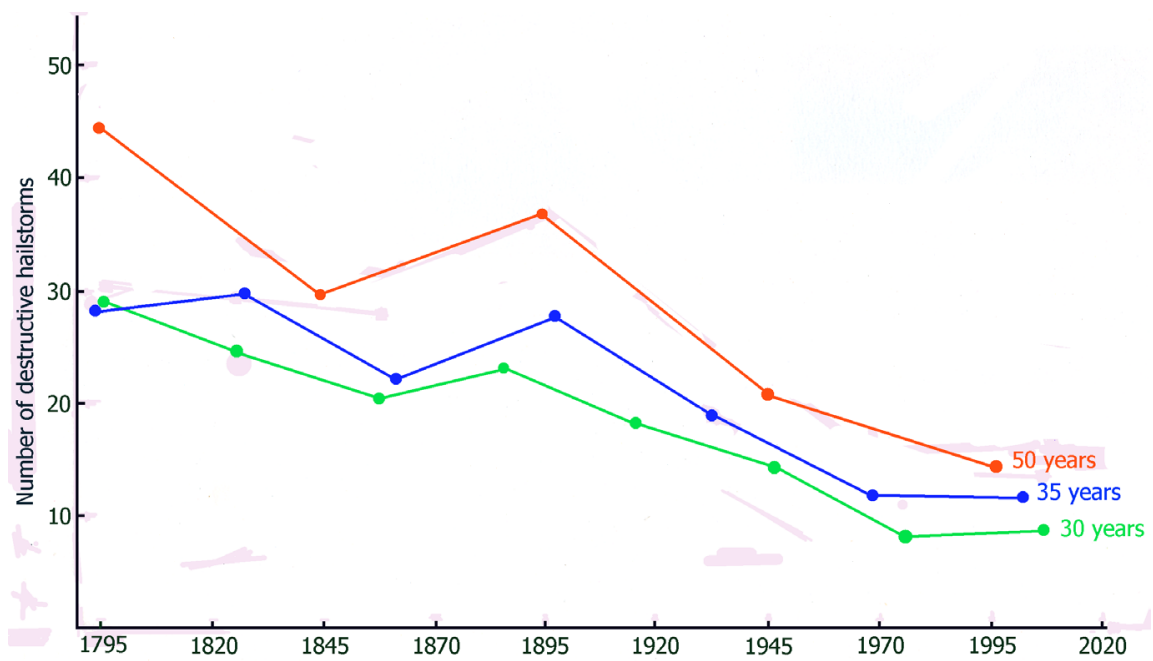

Figure 1. Frequency of destructive hailstorms using 50, 35, and 30 year non-overlapping time periods.

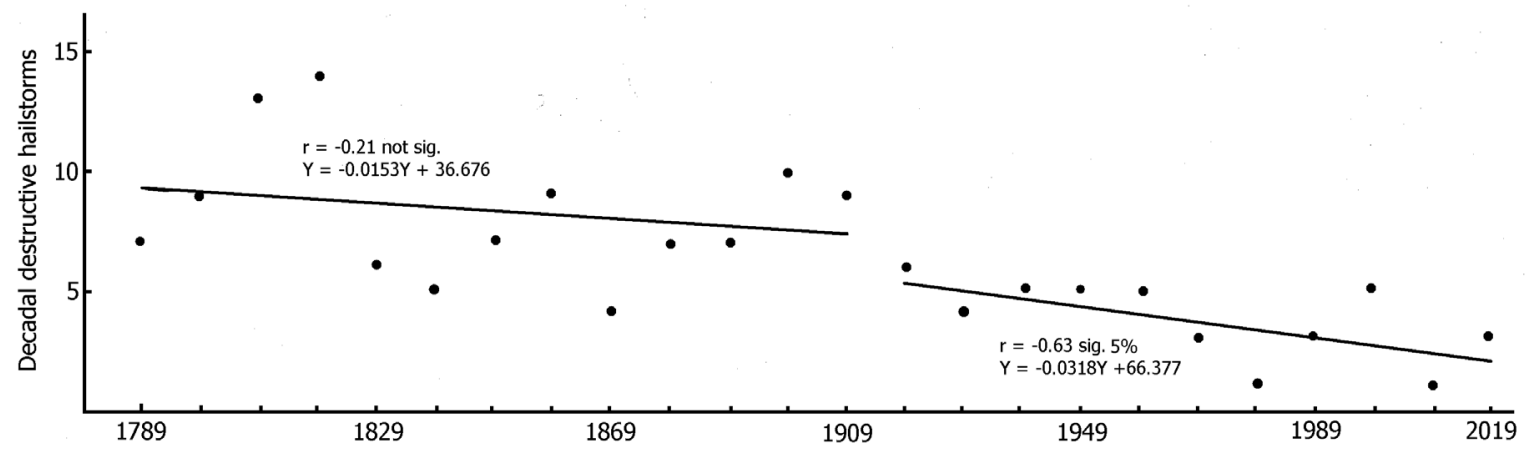

Figure 2. Decadal frequency of destructive hailstorms 1780-2019.

Table 2. Comparisons of destructive hail frequency.

\begin{tabular}{cccc}
\hline Time base (years) & Time periods & Mann Whitney U & Median frequency \\
\hline 10 & $1780-1909$ & 21.5 sig $2 \%$ & 9 \\
$1910-2019$ & & 3.0 \\
30 & $1780-1899$ & 0.5 sig $>0.2 \%$ & 29.5 \\
$1900-2019$ & & 15.5 \\
10 & $1780-1959$ & 17.5 sig $2 \%$ & 9.0 \\
$1960-2019$ & & 3.5 \\
30 & $1780-1959$ & 0.0 sig $>0.2 \%$ & 28 \\
& $1960-2019$ & & 13 \\
\hline
\end{tabular}

which are for two time bases and time periods. Also shown are the median frequency of hailstorms. All of these measures show a significant difference between the two different divisions and time bases of the data series. The greatest difference is between pre and post 1960 for a 30 year time base.

During the same time period the population of England and Wales rose from 
8.9 million in 1801, to 32.5 million in 1901 and 56.1 million in 2019. This would make the chances of events being recorded much greater with time. An increase in population density was shown by Martins et al. (2017) to be correlated to reported hailstorms in their study of destructive hailstorms in SE Brazil, although the range of density was generally lower than in England and Wales. Prior to 1800 the opportunities for stages 2 - 5 in the knowledge survival process of past events were very limited. We may never know the true extent of the hailstorm climatology pre 1800, and although Clark (2004) suggested a correction for newspaper coverage, it did not include taking the lower surface area of property into account. What is more telling is the negative correlation, not shown here, of population and H5+ frequency after 1900. It is possible that the chances of an H5+ event being recorded reached its peak by the mid $19^{\text {th }}$ century, and that any further increase in population thereafter made no significant difference to stage 2 of the knowledge gaining process.

\subsection{Maximum Hailstone Size}

Figure 3 shows the changes in maximum hailstone size for the past 570 years. There is a clear and statistically significant decline of maximum hail size over the whole period of record. Since the chances of destructive events that took place in remote and sparsely populated areas and go unrecorded rise rapidly before 1800 , it is likely that some events will have been missed. While there is some uncertainty, there is enough detail in the descriptions at least back to 1697 to have considerable confidence in their accuracy.

\section{Possible Causative Mechanisms}

There are several possible causes of the change in hailstorm frequency since 1780 . These include changes in the stability of air masses, the freezing level, and changes in the large scale wind pattern. These possible causes cannot be investigated in any detail for the whole 240 years. However, there are two possible variables which may be linked to the changes in hailstorm frequency which are amenable to study: temperature on the day of the event and particulate pollution from aviation and other sources. Data for both of these possible causes is available for analysis.

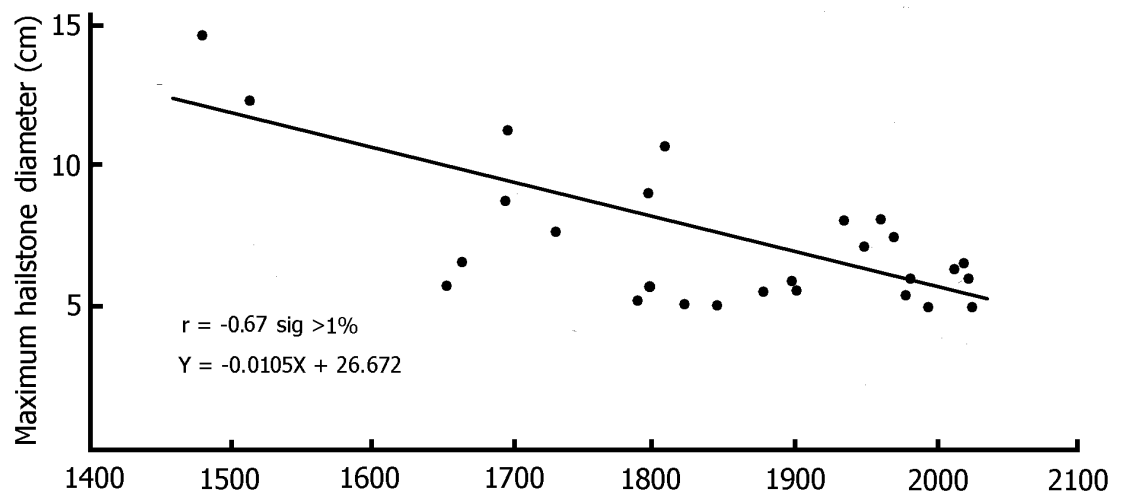

Figure 3. Changes in maximum hailstone diameter since the $15^{\text {th }}$ century. 
Temperature is expected to be an important variable since many destructive hailstorms take place during the summer months when temperatures are relatively high. The dramatic increase in air travel since 1950 is of potential interest in the current study because of the composition of aircraft exhaust. Aircraft contrails are often visible and the particulate matter within them would be expected to act as cloud and ice condensation nuclei. It is not possible to definitively prove that a particular factor or factors have led to the changes in $\mathrm{H} 5+$ frequency and hailstone size. In the period 1650-1780 the relatively low population density and the ability to report damage is a likely explanation for the low frequency, but the present study of hailstorm frequency begins in 1780. After this time the threefold increase in population would mean a greater chance of an event being recorded. The dramatic decline after 1910 is more problematical.

Hailstorms are often associated with hot weather and marked instability over a large height in the atmosphere (Petterssen, 1969) which occurs mainly in the summer over England and Wales. Therefore it seems sensible to first look at the part played by air temperature. Figure 4 shows the maximum CET (Central England Temperature) on the day of the storm for all $\mathrm{H} 5+$ events since 1889 when daily CET data are available https://www.metoffice.gov.uk/hadobs/hadcet/data/download.html. A range of $20 \mathrm{deg} C$ is associated with the events with a preference of +19 deg $\mathrm{C}$ to include $78 \%$ of all events. Daily values of average CET are also available from 1771. However, analysis of the trends of daily maximum CET failed to reveal any compelling trends which may have helped to explain the trend of hailstorm frequency. There is also the problem that the local temperature of each storm could be significantly different from CET and the effect of wind shear, which is associated with the occurrence of supercell thunderstorms and associated hailstorms, cannot be accounted for.

The effect of aviation on climate has been considered (IPCC, 1999) but no mention was made of its effect on hailstorms. Rosenfeld et al. (2008) summarised the radiative and nucleating effects of aerosols, but did not consider the effect of inputs from aviation. The growth of ice nuclei into hailstones is described by Houze (2014), emphasising the importance of riming as supercooled water is gathered by graupel. The release of latent heat by this process is huge and this contributes to more uplift. Wendisch et al. (2016) show how biomass burning produces more cloud condensation nuclei $(\mathrm{CCN})$ which in turn produce more smaller raindrops, while more ice nuclei (IN) can lead to an increase in glaciation temperature and a bigger number of smaller ice crystals. Similarly, a decline in orographic rainfall was associated with increasing air pollution in central China as estimated using visibility records (Rosenfeld et al., 2007). However, in the UK for the past 60 years visibility has improved (Singh, Bloss, \& Pope, 2017) and since visibility is mainly affected by surface to air pollution, perhaps a measure of air traffic over the UK may suggest an explanation.

Figure 5 shows the growth of take offs and landings https://www.gov.uk/government/collections/aviation-statistics. Since 1950 there 
has been a rapid rise to over two million air traffic movements per year. The possible effect of aviation can be assessed by using this data, the average distance travelled overland and the number of particles per unit weight of fuel (Herndon et al., 2005). The calculation is shown in Box 1 which gives a range of values for a Boeing 777-300ER and an Airbus A350-900 of 77,021 $\times 10^{7}$ and 55,427 $\times 10^{7}$ particles per $\mathrm{m}^{2}$ per day respectively. If this daily dose is allowed to occupy the lower $10,000 \mathrm{~m}$ of the atmosphere we get 77.0 and 55.4 particles $\mathrm{cm}^{-3}$ respectively.

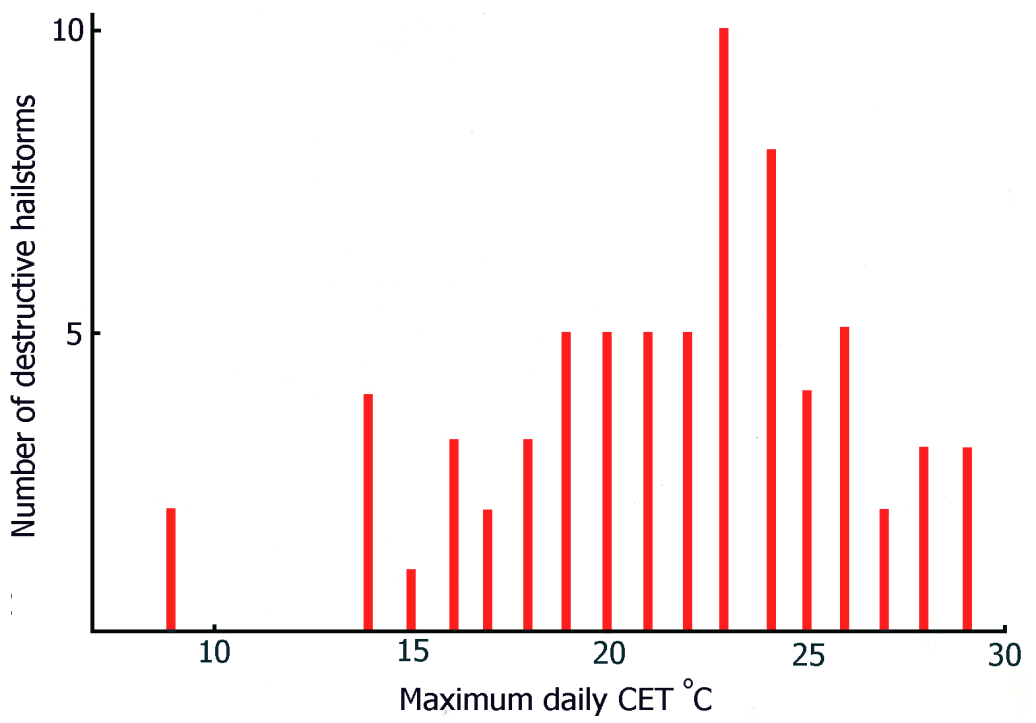

Figure 4. Frequency distribution of maximum CET on days with destructive hailstorms.

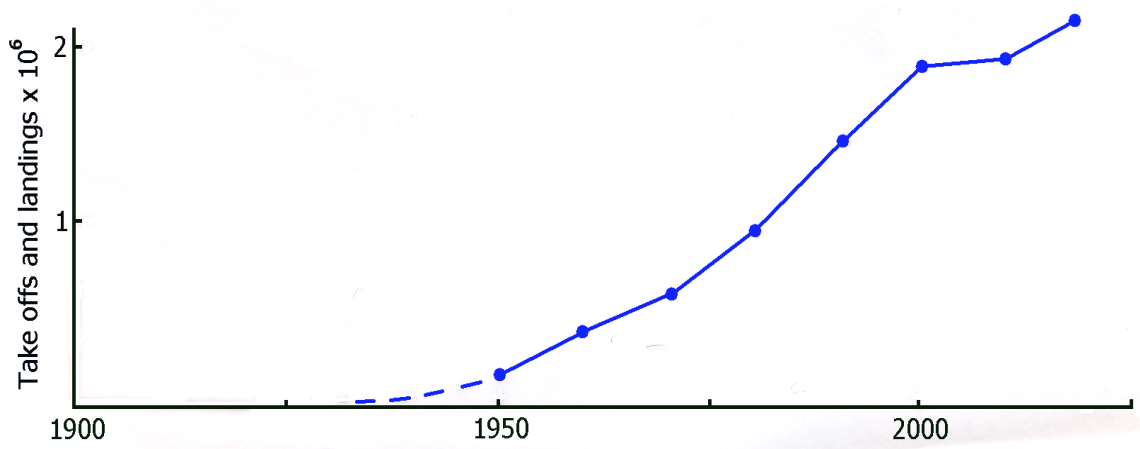

Figure 5. Changes in air transport in the UK (https://www.gov.uk/government/collections/aviation-statistics).

Box 1. Estimated input of particles from aircraft over the UK.

Estimated input of particles from aircraft over the UK

Boeing $777^{\star}$ uses $8.49 \mathrm{~kg} \cdot \mathrm{km}^{-1}$ fuel

Average distance travelled by aircraft over UK approximately $250 \mathrm{~km}$

In 2000 there were about 2 million take offs and landings (TOFL's)

Herndon et al. (2005) estimate there are $10^{16}$ particles released from burning of $1 \mathrm{~kg}$ fuel

The area of England and Wales is $151,000 \mathrm{~km}^{2}$

Number of particles day ${ }^{-1} \cdot \mathrm{m}^{-2}=\left(2 \times 10^{6} \times 8.49 \times 250 \times 10^{16}\right) / 365 \times 151,000 \times 10^{6}=77,021 \times 10^{7}$

*https://ipfs.io/ipfs/QmXoypizjW3WknFiJnKLwHCnL72vedxjQkDDP1mXWo6uco/wiki/Fuel_economy_i n_aircraft.html. 
These compare with a typical range of $10-200$ particles $\mathrm{cm}^{-3}$ for relatively unpolluted sites at Barrow (Alaska) and Jungfraujoch (Switzerland), (Schmale et al., 2018). Unfortunately background aerosol data prior to 1950 are not available but the results and comparison presented here suggest that the input from aviation could affect the processes of cloud condensation and ice nucleation. A background value of 10 particles $\mathrm{cm}^{-3}$ is equivalent to $10^{4} \mathrm{~m}^{-2}$. This is a factor of $7.7 \times$ $10^{6}$ less than the daily input from aviation at a high level in the atmosphere, or a factor of $385 \times 10^{3}$ at the higher end of the range given by Schmale et al. (2018). This last comparison does not allow for any wash out processes or for any possible build up of particles at high levels. The implied change in particulate matter since 1950 may help to explain the reduction in the frequency of severe hailstorms. The reduction of destructive hailstorms between 1909 and 1939 may be due to the fall in coal production from $292 \mathrm{Mt}$ in 1913 to $235 \mathrm{Mt}$ in 1939, or it may be a part of the natural variability of the events. Although most of the particulates which could function as ice condensation nuclei would not reach levels $+5000 \mathrm{~m}$ there may be lower level seeding that could affect the formation of hail. Therefore a separate analysis of coal production and hailstorm frequency from $1780-1939$ yielded $\mathrm{r}=-0.42$ and sig. $10 \%$ which is only of marginal significance.

An interesting study from 1952-2015 that investigated the effect of deliberate seeding of storm clouds in order to prevent hail formation (Dessens et al., 2015) showed that a cloud seeding generator burning about $9 \mathrm{~g}$ of silver iodide per hour caused a $50 \%$ decrease in hailfall energy on the most severe hailstorm days. This weight of silver iodide is only one third of the weight of carbon emitted from aircraft over England and Wales and strongly suggests that the effect of the natural experiment that aviation has provided for England and Wales on the frequency of destructive hailstorms may have validity.

\section{Comparison with Other Studies}

The damage caused by severe hailstorms has led to many studies of hail frequency and hailstone size. One of the first by Changnon \& Changnon (2000) showed that severe hailstorms had decreased in the US during the $20^{\text {th }}$ century. This study was followed by Balling \& Cerveny (2003) who, having made allowances for population growth and redistribution, and wealth, found no increase in the frequency of damaging hailstorms in the same area. Studies in Tibet (Zou et al., 2018), the Czech Republic (Brazdil et al., 2016a, 2016b), Greece (Sioutas, Meaden, \& Webb, 2009), China (Xie, Zhang, \& Wang, 2008), Argentina (Mezher, Doyle \& Barros, 2012), Finland (Tuovinen et al., 2009), China (Zhao et al., 2018) all report a decline in hail frequency. In parts of Brazil (Martins et al., 2017) showed however that reports of hailstorms increased with a rise in population density. The effect of better reporting was shown by Tuovinen et al. (2009), Shaefer et al. (2004) and Shuster et al. (2016) as time progressed. A study of 24 years' data from Ontario, Canada (Cao, 2008) has shown an increase in severe hailstorms, but since this is less than half one of the time periods used in the current data base of 
over 200 years length, more evidence that the increase is not just part of natural variability is called for. As regards hailstone size Xie et al. (2008), and Ni et al. (2017) both report decreases, although not as dramatic as in the present study.

None of the above studies analyse data that covers more than 200 years. However, there is a broad consistency where the data go back far enough, to show a steady increase in frequency due to better reporting, rather than by another cause. This is followed by a decline in frequency. Records that begin after 1850 tend to show a decline, although exceptions do occur (Kahraman et al., 2016).

Several studies have attempted to give an explanation for the changes in hailstorm frequency. Zou et al. (2018) suggested that warmer temperatures over Tibet led to reduced freezing in the hail producing clouds. Zhao et al. (2018) investigated several associations including the daily temperature range (DTR), minimum temperature, and convectively available potential energy (CAPE). Their results are in some ways contradictory since CAPE was found to be increasing while DTR decreased. Much more telling is the wide range of temperatures over which hailstorms occur (Figure 4). But with increased temperatures in England and Wales since 1800, hailstorm frequency has decreased, instead of increasing.

Aerosols have been implicated in changes of rainfall and hailstorm activity, but the results vary. For example Rosenfeld et al. (2007) showed that decreased visibility in parts of China has suppressed rainfall, while Andreae et al. (2004) showed that in Amazonia, forest fires lead to a delay in condensation and transfer of latent heat to higher levels in the atmosphere which lead to more severe hailstorms. In the UK Singh, Bloss \& Pope (2017) have shown that visibility has increased during the last 60 years which might be expected to allow more downward radiation and increased convection during the summer.

\section{The Future}

There has been a discrepancy between empirical studies of past hailstorm frequency and theoretical predictions for the future. This may have come about by the blinding effect of thunderstorms being, quite rightly, mainly associated with hot summer weather. This has led to the assumption that as temperatures are expected to rise in the $21^{\text {st }}$ century hailstorm frequency is predicted to rise (Brooks, 2013; Trapp et al., 2007; Botzen, Bouwer, \& van de Bergh, 2010; Brimelow, Burrows, \& Hanesiak, 2017). However, Sanderson et al. (2015) used a regional climate model (RCM) for the UK to suggest a decline in hail 21 - $50 \mathrm{~mm}$ diameter. Although they describe the distribution of simulated damaging hailstorms as being in reasonable agreement with the existing hailstorm climatology of Webb, Elsom, \& Meaden (2009), there are large areas in SE England whose recorded frequency is four times greater than what the RCM produced. All methods which have been used to predict the future must be able to adequately describe the past and, more especially, for the right reasons. We therefore call upon all those who currently use predictive models to reproduce the results since 1800 as shown in Figure 1 and Figure 2 of this paper. The past 50 years may have been a meteorological anomaly in England and Wales but the number and location of similar 
studies which have shown a downward trend in severe hailstorms suggest a more global than a national process mechanism. We do not have the upper air aerosol data for the past 200 years, but if the general weight of evidence is found to be correct, then the threat of destructive hailstorms may, for the next 30 years, be much lower than for the period 1800-1910 in England and Wales.

\section{Conclusion and Discussion}

Since 1910 there has been a dramatic drop in hailstorm frequency, while since the $15^{\text {th }}$ century maximum hailstone size has decreased. These changes cannot be due to an increased ability to record what happened after 1910. After 1950 it is suggested that increases in ice nuclei and cloud condensation nuclei have led to a dramatic drop in the frequency of destructive hailstorms. If this hypothesis turns out to be correct, then all else being equal, there will be a continuation of the low frequency of hailstorms in the near future.

There has been much concern about worsening environmental hazards associated with predicted temperature changes in the next 50 years. The results of this paper have provided several new twists to this tale. The first is a decrease in the frequency of destructive hailstorms. Second, hail in excess of $10 \mathrm{~cm}$ diameter has not been recorded for over 200 years in England and Wales. Third, the rise of air travel from the 1950's onwards may well have further contributed to the dramatic decline in events on the TORRO scale of H5+ since 1910. Although contrails are a visible manifestation of air traffic, particles released from aircraft are considerable, though not seen as pollutants at high altitudes. If another area other than the densely populated UK has a history of hailstorms and no passing or landing aircraft, it may serve as a control to the situation described here and could prove or call into question the effect of high-level air pollution on the frequency of destructive hailstorms.

\section{Acknowledgements}

The author would like to thank the two anonymous referees for their helpful comments that enabled me to improve an earlier version of the paper.

\section{Conflicts of Interest}

The author declares no conflicts of interest regarding the publication of this paper.

\section{References}

Andreae, M. O. et al. (2004). Clouds over the Amazon. Science, 303, 1337-1342. https://doi.org/10.1126/science.1092779

Balling, R. C., \& Cerveny, R. S. (2003). Compilation and Discussion of Trends in Severe Storms in the United States: Popular Perceptions v. Reality. Natural Hazards, 29, 103-112. https://doi.org/10.1023/A:1023674722282

Botzen, W. J., Bouwer, L. M., \& van de Bergh, J. C. J. M. (2010). Climate Change and 
Hailstorm Damage: Empirical Evidence and Implications for Agriculture and Industry. Resource and Energy Economics, 52, 341-362.

https://doi.org/10.1016/j.reseneeco.2009.10.004

Brazdil, R., Chroma, K., Valasek, H., \& Dolak, L. (2016a). A Long-Term Chronology of Summer Half-Year Hailstorms for South Moravia Czech Republic. Climate Research, 71, 91-109. https://doi.org/10.3354/cr01432

Brazdil, R., Chroma, K., Valasek, H., Dolak, L., \& Reznickova, L. (2016b). Damaging Hailstorms in South Moravia, Czech Republic, in the Seventeenth to Twentieth Centuries as Derived from Taxation Records. Theoretical and Applied Climatology, 123, 185-198. https://doi.org/10.1007/s00704-014-1338-1

Brimelow, J. C., Burrows, W. R., \& Hanesiak, J. M. (2017). The Changing Hail Threat over North America in Response to Anthropogenic Climate Change. Nature Climate Change, 7, 516-522. https://doi.org/10.1038/nclimate3321

Brooks, H. E. (2013). Severe Thunderstorms and Climate Change. Atmospheric Research, 123, 129-138. https://doi.org/10.1016/j.atmosres.2012.04.002

Burton, R. (1811). Admirable Curiosities, Rarities and Wonders in England Scotland and Ireland. London: George Smeaton.

Cao, Z. (2008). Severe Hail Frequency over Ontario, Canada: Recent Trend and Variability. Geophysical Research Letters, 35, L14803.

https://doi.org/10.1016/j.atmosres.2012.04.002

Changnon, S. A., \& Changnon, D. (2000). Long-Term Fluctuations in Hail Incidences in the United States. Journal of Climate, 13, 658-664. https://doi.org/10.1175/1520-0442(2000)013<0658:LTFIHI>2.0.CO;2

Clark, C. (2004). The Heat Wave over England and the Great Hailstorm in Somerset, July 1808. Weather, 59, 172-176. https://doi.org/10.1256/wea.04.04

Clark, M. R., Webb, J. D. C., \& Kirk, P. J. (2018). Fine-Scale Analysis of a Severe Hailstorm Using Crowd-Sourced and Conventional Observations. Meteorological Applications, 25, 472-492. https://doi.org/10.1002/met.1715

Curnock, N. (1949). John Wesley’s Journal 1703-1791. London: Epworth Press.

Dessens, J., Sanchez, J. L., Berthet, C., Hermids, L., \& Merino, A. (2015). Hail Prevention by Ground-Based Silver Iodide Generators: Results of Historical and Modern Field Projects. Atmospheric Research, 170, 98-111.

https://doi.org/10.1016/j.atmosres.2015.11.008

Doe, R. K. (2016). Extreme Weather: Forty Years of the Tornado and Storm Research Organisation (327 p.). Chichester: Wiley Blackwell. https://doi.org/10.1002/9781118949986

Emerson, J. D., \& Hoaglin, D. C. (1983). Resistant Lines for Y versus X. In D. C. Hoaglin, F. Mosteller, \& J. L. Tukey (Eds.), Understanding Robust and Exploratory Data Analysis (pp. 129-163). New York: Wiley.

Gunturi, P., \& Tippett, M. (2017). Impact of ENSO on U.S. Tornado and Hail Frequencies $(5$ p.). Willis Re.

Herndon, S. et al. (2005). Particulate Emissions from In-Use Commercial Aircraft. Aerosol Science and Technology, 39, 799-809. https://doi.org/10.1080/02786820500247363

Hobhouse, E. (1934). The Diary of a West Country Physician AD 1684-1726. London: Simpkin Marshall.

Houze, R. A. (2014). Cloud Dynamics, International Geophysics (Vol. 104, 432 p.). Amsterdam: Academic Press. 
IPCC (1999). Aviation and the Global Atmosphere. A Special Report of IPCC Working Groups I and III in Collaboration with the Scientific Assessment Panel to the Montreal Protocol on Substances that Deplete the Ozone Layer. Cambridge: Cambridge University Press.

Jeffery, R. W. (1933). Was It Wet or Fine? Being an Account of English Weather from Chronicles, Diaries and Registers. Two Volumes Available at the UKMO Archive, Exeter.

Kahraman, A., Tiler-Tanriover, S., Kadioglu, M., Schultz, D. M., \& Markowski, P. M. (2016). Severe Hail Climatology of Turkey. Monthly Weather Review, 144, 337-346. https://doi.org/10.1175/MWR-D-15-0337.1

Martins, J. A. et al. (2017). Climatology of Destructive Hailstorms in Brazil. Atmospheric Research, 184, 126-138. https://doi.org/10.1016/j.atmosres.2016.10.012

Mezher, R. N., Doyle, M., \& Barros, V. (2012). Climatology of Hail in Argentina. Atmospheric Research, 114-115, 70-82. https://doi.org/10.1016/j.atmosres.2012.05.020

Ni, X. et al. (2017). Decreased Hail Size in China since 1950. Science Reports, 7, Article No. 10913. https://doi.org/10.1038/s41598-017-11395-7

Petterssen, S. (1969). Introduction to Meteorology (3rd ed., 333 p.). New York: McGraw Hill.

Prein, A. F., \& Holland, G. J. (2018). Global Estimates of Damaging Hail Hazard. Weather and Climate Extremes, 22, 10-23. https://doi.org/10.1016/j.wace.2018.10.004

Rosenfeld, D., Dai, J., Yu, X., Yao, Z., Xu, X., Yang, X., \& Du, C. (2007). Inverse Relations between Amounts of Air Pollution and Orographic Precipitation. Science, 315, 1396-1398. https://doi.org/10.1126/science.1137949

Rosenfeld, D. et al. (2008). Flood or Drought: How Do Aerosols Affect Precipitation? Science, 321, 1309-1313. https://doi.org/10.1126/science.1160606

Sanderson, M. G., Hand, W. H., Groenemeijer, P., Boorman, P. M., Webb, J. D. C., \& McColl, L. J. (2015). Projected Changes in Hailstorms during the 21st Century over the UK. International Journal of Climatology, 35, 15-24. https://doi.org/10.1002/joc.3958

Schmale, J. et al. (2018). Long-Term Cloud Condensation Nuclei Number Concentration Particle Number Size Distribution and Chemical Composition Measurements at Regionally Representative Observatories. Atmospheric Chemistry and Physics, 18, 2853-2881. https://doi.org/10.5194/acp-18-2853-2018

Shaefer, J. T., Levit, J. J., Weiss, S. J., \& McCarthy, D. W. (2004). The Frequency of Large Hail over the Contiguous United States. In 14th Conference on Applied Climatology (3.3). Seattle, WA: American Meteorological Society.

Shuster, S. S., Blong, R. J., \& Speer, M. S. (2016). A Hail Climatology of the Greater Sydney Area and New South Wales Australia. International Journal of Climatology, 25, 1633-1650. https://doi.org/10.1002/joc.1199

Siegel, S. (1956). Non Parametric Statistics (312 p.). New York: McGraw-Hill.

Singh, A., Bloss, W. T., \& Pope, F. D. (2017). 60 Years of UK Visibility Measurements: Impact of Meteorological and Atmospheric Pollutants on Visibility. Atmospheric Chemistry and Physics, 17, 2085-2101. https://doi.org/10.5194/acp-17-2085-2017

Sioutas, M., Meaden, T., \& Webb, J. D. C. (2009). Hail Frequency, Distribution and Intensity in Northern Greece. Atmospheric Research, 96, 526-533.

https://doi.org/10.1016/j.atmosres.2008.09.023

Tablet of Memory (1811). Shewing Every Memorable Event in History. Printed for J Bumpus, London. 
Trapp, R. J., Diffenbough, N. S., Brooks, H. E., Baldwin, M. E., Robinson, E. D., \& Pal, J. S. (2007). Changes in Severe Thunderstorm Environment Frequency during the 21st Century Caused by Anthropogenically Enhanced Global Radiative Forcing. Proceedings of the National Academy of Sciences of the United States of America, 104, 19719-19723. https://doi.org/10.1073/pnas.0705494104

Tuovinen, J. P., Punkka, A. J., Rauhala, J., Hohti, H., \& Schultz, D. M. (2009). Climatology of Severe Hail in Finland 1930-2006. Monthly Weather Review, 137, 2238-2249. https://doi.org/10.1175/2008MWR2707.1

Walford, C. (1878). The Insurance Cyclopaedia (Volume 5). London: Charles and Edwin Layton.

Webb, J. D. C. (1988). Hailstorms and Intense Local Rainfalls in the British Isles. The International Journal of Meteorology, 13, 166-182.

Webb, J. D. C., \& Elsom, D. M. (2016). Severe Hailstorms in the United Kingdom and Ireland: A Climatological Survey with Recent and Historical Case Studies. In R. K. Doe (Ed.), Extreme Weather (pp. 155-194). Chichester: Wiley Blackwell. https://doi.org/10.1002/9781118949986.ch9

Webb, J. D. C., Elsom, D. M., \& Meaden, G. T. (2009). Severe Hailstorms in Britain and Ireland, a Climatological Survey and Hazard Assessment. Atmospheric Research, 93, 587-606. https://doi.org/10.1016/j.atmosres.2008.10.034

Wendisch, M. et al. (2016). Studying Tropical Deep Convective Clouds and Precipitation over Amazonia Using the New German Research Aircraft HALO. Bulletin of the American Meteorological Society, 97, 1885-1908.

https://doi.org/10.1175/BAMS-D-14-00255.1

Whistlecraft, O. (1851). Rural Gleanings. London: Hamilton Adams \& Co.

WMO (2017). WMO Guidelines on the Calculation of Climate Normals (18 p.). WMO No. 1203.

Wood, A. (1892). Life and Times of Anthony Wood, Antiquary, of Oxford. 1664-1681 Described by Himself. Oxford History Society.

Xie, B., Zhang, Q., \& Wang, Y. (2008). Trends in Hail in China during 1960-2005. Geophysical Research Letters, 35, L13801. https://doi.org/10.1029/2008GL034067

Zhao, W. et al. (2018). Declining Hailstorm Frequency in China during 1961-2015 and Its Potential Influential Features. International Journal of Climatology, 38, 4116-4126. https://doi.org/10.1002/joc.5556

Zou, T., Zhang, Q., Li, W. L., \& Li, J. (2018). Responses of Hail and Storm Days to Climate Change in the Tibetan Plateau. Geophysical Research Letters, 45, 4485-4493. https://doi.org/10.1029/2018GL077069 